\title{
Purification and kinetics of phenylpropanoid $O$-methyltransferase activities from Brassica oleracea
}

\author{
Emidio De Carolis and Ragai K. Ibrahim ${ }^{1}$ \\ Plant Biochemistry Laboratory, Department of Biology, Concordia University, \\ Montréal, Que., Canada H3G IM8 \\ Received April 21, 1989
}

\begin{abstract}
De Carolis, E., and IBrahim, R. K. 1989. Purification and kinetics of phenylpropanoid $O$-methyltransferase activities from Brassica oleracea. Biochem. Cell Biol. 67: 763-769.

Two phenylpropanoid $O$-methyltransferase isoforms were purified to homogeneity from young cabbage leaves. They catalyzed the meta-O-methylation of caffeic and 5-hydroxyferulic acids to ferulic and sinapic acids, respectively. Both isoforms I and II exhibited different elution patterns from a Mono Q column, distinct apparent pIs on chromatofocusing, different product ratios, and stability on adenosine-agarose affinity column. On the other hand, both isoforms had similar apparent molecular masses ( 42 kilodaltons) and a $\mathrm{pH}$ optimum of 7.6. They exhibited no requirement for divalent cations and were both irreversibly inhibited by iodoacetate. Substrate interaction kinetics of the more stable isoform I, using the 5-hydroxyferulic acid and $S$-adenosyl-L-methionine, gave converging lines. Product inhibition studies showed competitive inhibition between $S$-adenosyl-L-methionine and $S$-adenosyl-L-homocysteine and noncompetitive inhibition between the phenylpropanoid substrate and its methylated product. The kinetic patterns are consistent with an ordered bi bi mechanism, where $S$-adenosyl-L-methionine is the first substrate to bind and $S$-adenosyl-L-homocysteine is the last product released.
\end{abstract}

Key words: phenylpropanoid $O$-methyltransferase, purification, isoforms, adenosine-agarose affinity chromatography, kinectic mechanism.

De Carolis, E., et Ibrahim, R. K. 1989. Purification and kinetics of phenylpropanoid $O$-methyltransferase activities from Brassica oleracea. Biochem. Cell Biol. 67 : 763-769.

Nous avons purifié jusqu'à homogénéité deux isoformes de la phénylpropanoïde $O$-méthyltransférase à partir de jeunes feuilles de chou. Elles catalysent la méta- $O$-méthylation de l'acide caféique en acide férulique et de l'acide 5-hydroxyférulique en acide sinapique. Les deux isoformes, I et II, présentent des profils d'élution différents de la colonne Mono Q, des pI apparents distincts par chromatofocalisation, des rapports de produits différents et une stabilité différente sur colonne d'affinité d'adénosine-agarose. Par ailleurs, les deux isoformes ont des masses moléculaires apparents (42 kilodaltons) similaires et le même $\mathrm{pH}$ optimum de 7,6. Elles ne requièrent pas de cations divalents et les deux sont inhibées de façon irréversible par l'iodoacétate. La cinétique d'interaction de l'isoforme I avec l'acide 5-hydroxyférulique et la $S$-adénosyl-L-méthionine comme substrats donne des lignes convergentes. Les études d'inhibition par le produit montrent une inhibition compétitive entre la $S$-adénosyl-L-méthionine et la $S$-adénosyl-Lhomocystéine et une inhibition non compétitive entre le substrat phénylpropanoïde et son produit méthylé. Les profils cinétiques sont compatibles avec un mécanisme bi bi ordonné où la $S$-adénosyl-L-méthionine est le premier substrat à se lier et la $S$-adénosyl-L-homocystéine est le dernier produit libéré.

Mots clés : phénylpropanoïde $O$-méthyltransférase, purification, isoformes, chromatographie d'affinité sur adénosineagarose, mécanisme cinétique.

[Traduit par la revue]

\section{Introduction}

Phenylpropanoid compounds are among the most common natural constituents of vascular plants. Two of their derivatives, ferulic (3-methoxy-4-hydroxycinnamic) and sinapic (3,5-dimethoxy-4-hydroxycinnamic) acids, are known precursors of lignin. They are formed by the enzymatic $O$-methylation of caffeic (3,4-dihydroxycinnamic) and 5-hydroxyferulic acids, respectively.

Substrate specificity studies of phenylpropanoid $O$-methyltransferase (EC 2.1.1.6) have established that the gymnosperm enzyme accepts only caffeic acid as a substrate, whereas the angiosperm $O$-methyltransferase can utilize both caffeic and 5-hydroxyferulic acids as the methyl acceptors (Shimada et al. 1970). These results correlate well with the

ABBREVIATIONS: NMR, nuclear magnetic resonance; HPLC, high pressure liquid chromatography; TLC, thin-layer chromatography; FPLC, fast protein liquid chromatography; SDS-PAGE, sodium dodecyl sulfate - polyacrylamide gel electrophoresis; $\mathrm{kDa}$, kilodalton(s); dpm, disintegrations per minute.

${ }^{1}$ Author to whom all the correspondence should be addressed. presence of guaiacyl residues in gymnosperm lignin and both guaiacyl and syringyl residues in angiosperms (Sarkanen and Ludwig 1971).

Whereas phenylpropanoid $O$-methyltransferases have been studied in various tissues (for review see Poulton 1981), none have been purified to homogeneity. More recently, however, Hermann et al. (1987) have achieved the purification of three homogeneous phenylpropanoid $O$-methyltransferase isoenzymes from tobacco leaves infected with tobacco mosaic virus, although their enzyme specificities were not thoroughly studied. Except for the enzymatic $O$-methylations of 5- and 8-hydroxyfuranocoumarins which have been reported to be catalyzed by two distinct $O$-methyltransferases (Thompson et al. 1978), no studies have so far demonstrated position specificity of the phenylpropanoid $O$-methyltransferase. Furthermore, it is not known with certainty whether the $O$-methylations of caffeic and 5 -hydroxyferulic acids are mediated by one or two distinct enzymes. This prompted us to purify and characterize the phenylpropanoid $O$-methyltransferase from cabbage leaves and to study, for the first time, its kinetic mechanism and kinetic parameters. 


\section{Materials and methods}

\section{Chemicals}

S-Adenosyl-L-[ methyl $\left.-{ }^{14} \mathrm{C}\right]$ methionine $(47 \mathrm{mCi} / \mathrm{nmol} ; 1 \mathrm{Ci}=$ $37 \mathrm{GBq}$ ) was purchased from ICN Radiochemicals (Irvine, CA). Unlabeled $S$-adenosyl-L-methionine was obtained from Boehringer-Mannheim (Federal Republic of Germany). 5-Hydroxyferulic acid was synthesized by the condensation of 3-methoxy-4,5-dihydroxybenzaldehyde with malonic acid (Vorsatz 1936). Its identification and purity were confirmed by ${ }^{13} \mathrm{C}-\mathrm{NMR}$ and HPLC analysis, respectively. Caffeic, ferulic, sinapic, and 3,4,5-trihydroxycinnamic acids were purchased from Fluka (Ronkonkoma, NY) and their purity was confirmed by TLC and HPLC. Sephadex G-100, DEAE-Sephacel, Polybuffer 74, Mono Q HR 5/5, Mono P HR 5/20, and the FPLC system were from Pharmacia (Uppsala, Sweden). Adenosine-agarose affinity support and Dowex 1 X2 anion-exchange resin were obtained from P-L Biochemicals (Milwaukee, WI) and Bio-Rad Laboratories (Richmond, CA), respectively. All other chemicals used were of analytical grade.

\section{Buffer systems}

The following buffers were used: A, $200 \mathrm{mM}$ Tris- $\mathrm{HCl}$ ( $\mathrm{pH} 7.6$ ) containing $5 \mathrm{mM}$ ethylenediamine tetraacetic acid, $10 \mathrm{mM}$ diethylammonium diethyldithiocarbamate, and $14 \mathrm{mM}$ 2-mercaptoethanol; B, $50 \mathrm{mM}$ Tris- $\mathrm{HCl}$ ( $\mathrm{pH} 7.6$ ) containing $14 \mathrm{mM}$ 2-mercaptoethanol. All buffers used were degassed and filtered through a $0.45-\mu \mathrm{m}$ filter before being used.

\section{Plant material}

Brassica oleracea L. (Danish baldhead) seeds were obtained from a commercial source and germinated in potting soil under greenhouse conditions. The first, two to three fully expanded leaves of 6-week-old plants were used for enzyme extraction,

\section{Enzyme extraction}

Unless stated otherwise, all extraction and purification procedures were carried out at $4^{\circ} \mathrm{C}$. Approximately $300 \mathrm{~g}$ of deveined leaves were homogenized in a Waring blender containing Polyclar AT $(10 \% \mathrm{w} / \mathrm{w})$ and buffer A $(1: 4 \mathrm{w} / \mathrm{v})$. The slurry was filtered through a double layer of nylon mesh and centrifuged at $15000 \times \mathrm{g}$ for $15 \mathrm{~min}$. The supernatant was stirred for $15 \mathrm{~min}$ with Dowex $1 \mathrm{X} 2(10 \% \mathrm{w} / \mathrm{v})$, which had previously been equilibrated in buffer $\mathrm{A}$. The filtrate was fractionated with solid ammonium sulfate and the protein that precipitated between 35 and $80 \%$ salt saturation was collected by centrifugation.

\section{Enzyme purification}

\section{Sephadex G-100 chromatography}

The ammonium sulfate pellet was solubilized in the minimum amount of buffer B and then chromatographed on a Sephadex G-100 column $(5 \times 55 \mathrm{~cm})$, which had previously been equilibrated in the same buffer. The protein fractions with $O$-methyltransferase activity were pooled and the protein was precipitated with $80 \%$ ammonium sulfate. The resulting pellet was resuspended in the minimum amount of buffer B and desalted on a Sephadex G-25 column using the same buffer.

\section{DEAE-Sephacel chromatography}

The desalted protein with $O$-methyltransferase activity was subjected to anion-exchange chromatography on a DEAE-Sephacel column $(2.5 \times 8 \mathrm{~cm})$, which had previously been equilibrated in buffer B. The enzyme activity was eluted with $500 \mathrm{~mL}$ of a linear $(0-500 \mathrm{mM})$ gradient of $\mathrm{KCl}$ in buffer $\mathrm{B}$.

\section{Chromatography on Mono $Q$ column}

The active fractions from the above column were desalted on Sephadex G-25, and then subjected to ion-exchange chromatography on a Mono $Q$ column using the FPLC system. The column was previously equilibrated with buffer $B$ and the bound protein was eluted using a $50 \mathrm{~mL}$ linear $(0-300 \mathrm{mM})$ gradient of
$\mathrm{KCl}$ in buffer $\mathrm{B}$, at a flow rate of $0.5 \mathrm{~mL} / \mathrm{min}$. One-millilitre fractions were collected for the assay of $O$-methyltransferase activity.

\section{Affinity chromatography}

The active fractions from the Mono $Q$ column were directly applied to an adenosine-agarose affinity column $(1 \times 7 \mathrm{~cm})$ (Dumas et al. 1988), which had previously been equilibrated with buffer B. The column was washed with $15 \mathrm{~mL}$ of the same buffer, followed by $15 \mathrm{~mL}$ of $500 \mathrm{mM} \mathrm{KCl}$ in buffer $\mathrm{B}$. The enzyme activity was then eluted using a $50 \mathrm{~mL}$ linear $(0-0.5 \mathrm{mM})$ gradient of $S$-adenosyl-L-methionine in buffer B, and 1-mL fractions were collected and assayed for enzyme activity.

\section{Chromatofocusing on Mono $P$}

The $O$-methyltransferase activity that eluted from DEAESephacel was desalted on Sephadex G-25 column, before being applied to a chromatofocusing column (Mono P HR 5/20). The latter was washed with three column volumes of buffer B and the enzyme activity was eluted with $60 \mathrm{~mL}$ of polybuffer 74 iminodiacetic acid $(1: 10 \mathrm{v} / \mathrm{v})(\mathrm{pH} \mathrm{4.0)}$ containing $14 \mathrm{mM}$ 2-mercaptoethanol, at a flow rate of $0.3 \mathrm{~mL} / \mathrm{min}$. One-millilitre fractions were collected in $0.5 \mathrm{~mL}$ of $0.2 \mathrm{M}$ Tris- $\mathrm{HCl}(\mathrm{pH} 8.0)$ and assayed for enzyme activity.

\section{O-Methyltransferase activity}

The assay mixture contained $100 \mu \mathrm{M}$ of the phenolic substrate, $100 \mu \mathrm{M} S$-adenosyl-L-methionine (containing $0.05 \mu \mathrm{Ci}$; $1 \mathrm{Ci}=37 \mathrm{GBq}$ ), and up to $50 \mu \mathrm{g}$ protein (in $50 \mathrm{mM}$ Tris- $\mathrm{HCl}$, $\mathrm{pH}$ 7.6), in a final volume of $100 \mu \mathrm{L}$. The enzyme reaction was started by the addition of protein and the mixture was incubated for $30 \mathrm{~min}$ at $30^{\circ} \mathrm{C}$. The reaction was stopped by the addition of $10 \mu \mathrm{L}$ of $6 \mathrm{~N} \mathrm{HCl}$, and the methylated products formed were extracted in $250 \mu \mathrm{L}$ of ethyl acetate. An aliquot (ca. $100 \mu \mathrm{L}$ ) of the organic phase was counted for radioactivity in a toluene-based scintillation liquid, using a LKB 1217 Rackbeta liquid scintillation counter. The remaining fraction was used for identification of the reaction products. The latter were identified by cochromatography with authentic samples on TLC (cellulose-silica, 1:1 w/w) using benzene - acetic acid - water ( $2: 3: 1$ by volume) as the solvent system. The developed chromatograms were visualized under UV light $(366 \mathrm{~nm})$ and then autoradiographed on X-ray film.

\section{Analysis of kinetic data}

It was established that the reaction velocity was linear with respect to time for at least $60 \mathrm{~min}$ at all substrate concentrations. Substrate interaction kinetics was fitted to Eq. 1.

$$
\text { [1] } V=\frac{V_{\max }[\mathrm{A}][\mathrm{B}]}{K_{\mathrm{ia}} K_{\mathrm{b}}+[\mathrm{A}] K_{\mathrm{b}}+[\mathrm{B}] K_{\mathrm{a}}+[\mathrm{A}][\mathrm{B}]}
$$

which represents a bi bi mechanism. $\mathrm{A}$ and $\mathrm{B}$ are the varied substrates, $K_{\mathrm{a}}$ and $K_{\mathrm{b}}$ are the respective Michaelis-Menten constants, and $V_{\max }$ is the maximum velocity. All data from inhibition studies were fitted to the equations for competitive (Eq. 2) and noncompetitive (Eq. 3) inhibition.

$$
\begin{aligned}
& V=\frac{V_{\max }}{1+K_{\mathrm{a}} /[\mathrm{A}]+K_{\mathrm{a}}[\mathrm{I}] / K_{\mathrm{I}}[\mathrm{A}]} \\
& V=\frac{V_{\max }}{1+K_{\mathrm{a}} /[\mathrm{A}]+K_{\mathrm{a}}[\mathrm{I}] / K_{\mathrm{ia}}+[\mathrm{I}] / K_{\mathrm{I}}}
\end{aligned}
$$

A represents the variable substrate, $I$ is the product (inhibitor) of the reaction, and $K_{1}$ is the inhibitor constant. The data are presented as double-reciprocal plots, which were fitted by linear regression analysis and applied to the appropriate equation (Segel 1975).

\section{Molecular mass determination}

The apparent molecular mass of the phenylpropanoid $O$-methyltransferase was determined by SDS-PAGE according to the method of Weber and Osborn (1969). A 4\% stacking gel and 
TABLE 1. Purification of the phenylpropanoid O-methyltransferase from Brassica oleraceae ${ }^{a}$

\begin{tabular}{|c|c|c|c|c|c|c|c|c|}
\hline \multirow[b]{2}{*}{ Step } & \multirow{2}{*}{$\begin{array}{l}\text { Total } \\
\text { protein } \\
(\mathrm{mg})\end{array}$} & \multicolumn{2}{|c|}{$\begin{array}{l}\text { Specific activity } \\
\text { (pkat/mg) }\end{array}$} & \multicolumn{2}{|c|}{$\begin{array}{c}\text { Total } \\
\text { activity (pkat) }\end{array}$} & \multirow{2}{*}{$\begin{array}{c}\text { Ratio } \\
\text { SA/FA }\end{array}$} & \multirow{2}{*}{$\begin{array}{l}\text { Purification } \\
\text { ( } n \text {-fold })\end{array}$} & \multirow{2}{*}{$\begin{array}{l}\text { Yield } \\
(\%)\end{array}$} \\
\hline & & SA & FA & SA & FA & & & \\
\hline Dowex & 600 & 1.20 & 0.40 & 720 & 240 & 3.0 & - & 100 \\
\hline Sephadex G-100 & 140 & 4.40 & 1.50 & 616 & 210 & 2.9 & 4 & 86 \\
\hline DEAE-Sephacel & 9.4 & 12.5 & 4.20 & 118 & 39.5 & 3.0 & 10 & 17 \\
\hline \multicolumn{9}{|l|}{ Mono Q } \\
\hline I & 2.5 & 19.0 & 10.8 & 48.0 & 27.0 & 1.8 & 16 & 9 \\
\hline II & 2.1 & 16.0 & 6.10 & 34.0 & 13.0 & 2.8 & 13 & 5 \\
\hline \multicolumn{9}{|c|}{ Adenosine-agarose } \\
\hline I & $<0.025^{b}$ & $>6.8 \times 10^{3}$ & $>3.9 \times 10^{3}$ & $<171$ & $<98.0$ & $1.8^{c}$ & $>5660$ & $<24$ \\
\hline II & $<0.025$ & \multicolumn{2}{|c|}{ No activity } & - & - & - & - & - \\
\hline
\end{tabular}

Note: SA, sinapic acid; FA, ferulic acid.

${ }^{a}$ The $O$-methyltransferase activities were assayed as described in the Materials and methods using 5-hydroxyferulic and caffeic acids. The yield and purification are based on the enzyme activity with 5-hydroxyferulic acid.

${ }^{b}$ The minimum detectable value using the Bio-Rad method.

${ }^{\mathrm{C}}$ Based on dpm $(60 \mathrm{dpm}=1 \mathrm{~Bq})$.

a $12 \%$ separating gel were used and $20 \mu \mathrm{L}$ of a mixture of standard protein marker solution, containing bovine serum albumin (66 kDa), ovalbumin (45 kDa), glyceraldehyde-3-phosphate dehydrogenase (36 kDa), carbonic anhydrase (29 kDa), and trypsinogen $(24 \mathrm{kDa})$, was applied on to the stacking gel. The gels were stained with silver nitrate.

\section{Protein estimation}

The protein concentration was estimated according to the method of Bradford (1976) using the Bio-Rad reagent and bovine serum albumin as standard protein.

\section{Enzyme purification}

Results

The phenylpropanoid $O$-methyltransferase of Brassica leaves was purified by ammonium sulfate precipitation and successive chromatography on Sephadex G-100, DEAESephacel, Mono Q, and adenosine-agarose columns (Table 1). Both preliminary steps involving gel filtration and conventional anion-exchange chromatography were required to eliminate most of the extraneous proteins and contaminating pigments.

Chromatography of the partially purified enzyme preparation (DEAE-Sephacel fractions) on Mono $Q$ resulted in the separation of two distinct $O$-methylating activities (Fig. 1 and Table 1), which eluted at $120 \mathrm{mM}$ (isoform I) and $150 \mathrm{mM}$ (isoform II) salt. Both isoforms were free of contamination by the flavonoid $O$-methyltransferase, which eluted at $260 \mathrm{mM}$ salt (data not shown). When the DEAESephacel fractions were chromatographed on a Mono $\mathrm{P}$ column, isoforms I and II were resolved at pH 4.9 and 4.7, respectively.

Further purification of each isoform was achieved by affinity chromatography on an adenosine-agarose column (Fig. 2). Both isoforms were eluted with the cosubstrate $S$-adenosyl-L-methionine at $0.3 \mathrm{mM}$ and appeared homogeneous on SDS-PAGE (Fig. 3). However, whereas isoform I exhibited a significant increase in specific activity (Table 1), isoform II lost its catalytic activity possibly owing to instability.

This purification protocol resulted in an increase of specific activity of 5660 -fold as compared with the crude preparation. The homogeneous isoform I had a specific activity of ca. $6.8 \mathrm{nkat} / \mathrm{mg}$ with 5-hydroxyferulic acid as the

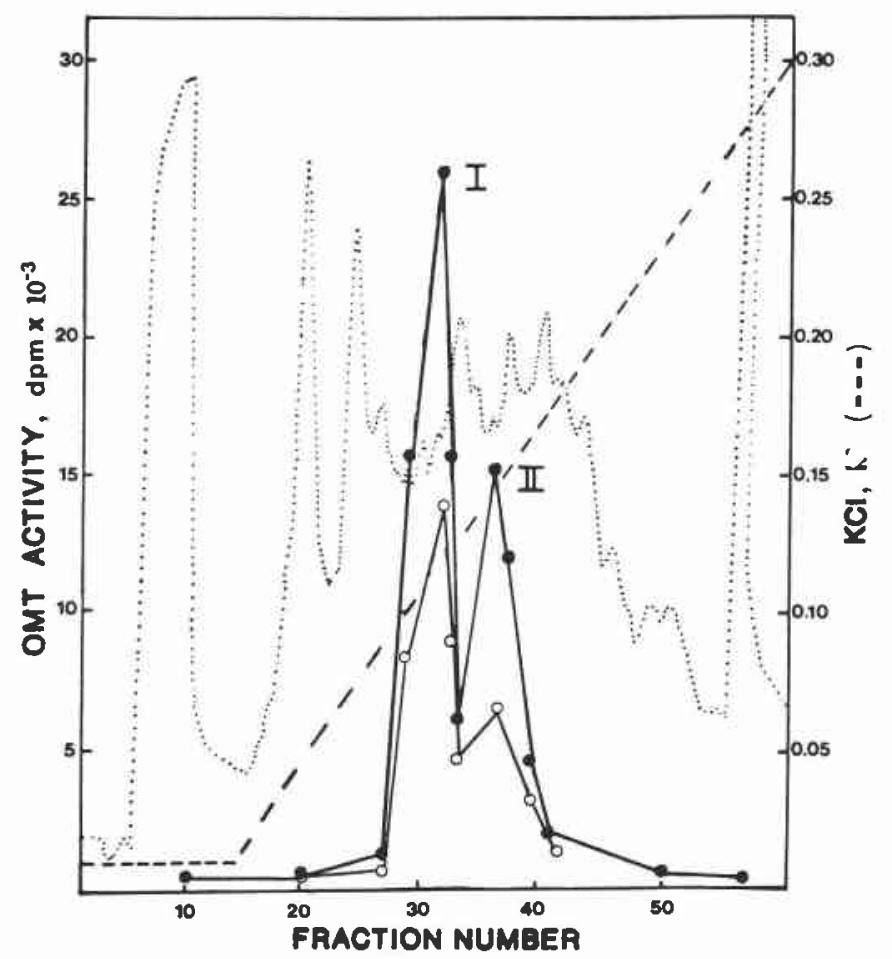

FIG. 1. Elution profile of phenylpropanoid $O$-methyltransferase by anion-exchange chromatography using a Mono $Q$ column. The column was equilibrated in buffer B and a linear (0-300 mM) gradient of $\mathrm{KCl}$ in buffer B was applied. One-millilitre fractions were collected and assayed for enzyme activity against 5-hydroxyferulic (•) and caffeic $(O)$ acids. The absorbance (..) was monitored at $280 \mathrm{~nm}$. OMT, phenylpropanoid $O$ methyltransferase.

substrate (Table 1). The purified enzyme represented approximately $0.0003 \%$ of total protein.

\section{Product ratio}

The ratio of sinapic acid to ferulic acid formed did not change during the early steps of enzyme purification. However, further purification of the enzyme on Mono Q resulted in a decline of the product ratio for isoform $\mathrm{I}$, in contrast with that of isoform II. Similar behavior was observed on chromatofocusing of both isoforms (Table 2). 


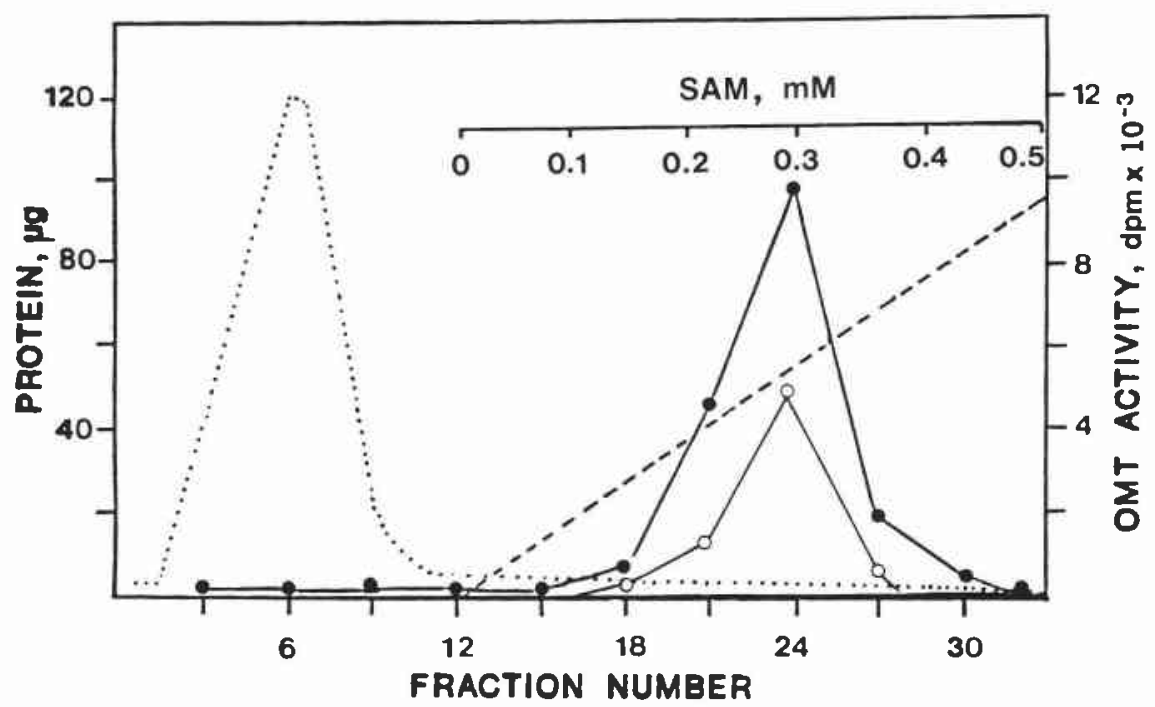

FIG. 2. Elution profile of isoform I after affinity chromatography on adenosine-agarose. The column was washed with five bed volumes of $0.5 \mathrm{M} \mathrm{KCl}$ in buffer $\mathbf{B}$. The bound protein was eluted using a linear $(0-0.5 \mathrm{mM})$ gradient of $S$-adenosyl-L-methionine in buffer B (- - ). One-millilitre fractions were collected and assayed for enzyme activity against 5-hydroxyferulic ( $\bullet$ ) and caffeic $(O)$ acids. The protein content (..$)$ in each fraction was measured by the method of Bradford (1976). SAM, S-adenosyl-L-methionine.

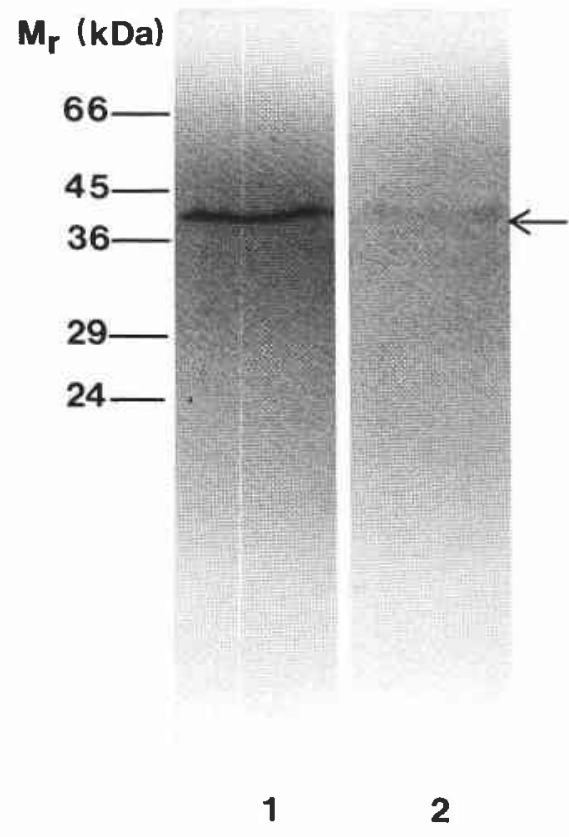

FIG. 3. SDS-PAGE of the purified $O$-methyltransferase isoforms I (lane 1) and II (lane 2). The amount of protein applied was about equivalent to $200 \mathrm{ng}$ bovine serum albumin, as determined from serial dilution of a standard protein. $\boldsymbol{M}_{\mathrm{r}}$, relative mass.

\section{Enzyme properties \\ Stability}

The partially purified isoforms I and II (Mono $\mathrm{Q}$ fractions) maintained $90 \%$ of their activity over $72 \mathrm{~h}$ when stored at $0-4^{\circ} \mathrm{C}$. However, the addition of $10 \%$ glycerol (v/v) and $10 \mathrm{mM}$ dithioerythritol maintained the enzyme activity for 1 month when stored at $-20^{\circ} \mathrm{C}$. On the other hand, the homogeneous isoform I was only stable for $24 \mathrm{~h}$ when stored under the same conditions.

\section{pH optimum}

The $\mathrm{pH}$ optimum for the methylation of 5-hydroxyferulic acid was studied in several buffers between pH 6 and 9.5 .
Optimum activity was found to be at pH 7.6 in $50 \mathrm{mM}$ Tris- $\mathrm{HCl}$. A change of one $\mathrm{pH}$ unit resulted in a $10 \%$ drop in enzyme activity.

\section{Substrate specificity}

The activity of both isoforms (Mono Q fractions) was found to be almost identical against a variety of substrates when assayed at $100 \mu \mathrm{M}$ concentration. These were in the following descending order: 5-hydroxyferulic acid $>$ caffeic acid $>$ quercetin $>3,4,5$-trihydroxycinnamic acid $>$ esculetin. Such compounds as the chlorogenic, $m$-coumaric, and p-coumaric acids as well as the 2,5- and 3,4-dihydroxybenzoic acids, did not serve as methyl acceptors.

\section{Other properties}

The two isoforms exhibited no requirement for divalent cations. On the other hand, there was an absolute requirement for the SH-group reducing agents 2-mercaptoethanol and dithioerythritol. The enzyme activity of both isoforms was completely inhibited by the addition of $1 \mathrm{mM}$ iodoacetate. This inhibition was not restored after the addition of 2-mercaptoethanol and (or) dithioerythritol. On the other hand, neither $N$-ethylmaleimide nor iodoacetamide demonstrated any significant inhibition when tested at 1 or $10 \mathrm{mM}$.

The homogeneous isoforms I and II migrated as single bands on SDS-PAGE as observed by staining with silver nitrate (Fig. 3, lanes 1 and 2). The molecular mass of each isoform was estimated to be $42 \pm 2 \mathrm{kDa}$ when compared with standard protein markers. Furthermore, isoform I appeared more intense than isoform II, suggesting that it is the major enzyme form in this tissue.

\section{Kinetics of the phenylpropanoid O-methyltransferase}

The kinetic studies were performed using 5-hydroxyferulic acid as the substrate and the partially purified isoform $I$ as the enzyme source. Preliminary studies indicated that substrate interaction gave Michaelis-Menten kinetics and no apparent inhibition was observed when saturating with the phenolic substrate and cosubstrate. Substrate interaction kinetics with 5-hydroxyferulic acid as the variable substrate 
TABLE 2. Product ratio of sinapic acid to ferulic acid of the two $O$-methyltransferase isoforms ${ }^{a}$

\begin{tabular}{|c|c|c|}
\hline & Mono Q & Mono P \\
\hline Isoform I & 1.8 & 1.7 \\
\hline Isoform II & 2.8 & 2.5 \\
\hline \multicolumn{3}{|c|}{$\begin{array}{l}{ }^{a} \text { Using the standard enzyme assay as } \\
\text { described in Materials and methods. }\end{array}$} \\
\hline \multicolumn{3}{|c|}{$\begin{array}{c}\text { TABLE 3. Kinetic parameters } \\
\text { of the phenylpropanoid } O \text { - } \\
\text { methyltransferase }\end{array}$} \\
\hline
\end{tabular}

Kinetic parameter

\begin{tabular}{lr}
\hline$K_{\mathrm{a}}$ & $55 \mu \mathrm{M}$ \\
$K_{\mathrm{b}}$ & $20 \mu \mathrm{M}$ \\
$K_{\mathrm{ia}}$ & $100 \mu \mathrm{M}$ \\
$K_{\mathrm{iq}}$ & $15 \mu \mathrm{M}$ \\
$K_{\mathrm{ip}}$ & $2000 \mu \mathrm{M}$ \\
\hline \multicolumn{2}{c}{ Note: a, S-adenosyl-L-methionine; } \\
b, 5-hydroxyferulic acid; p, sinapic acid; \\
q, $S$-adenosyl-L-homocysteine.
\end{tabular}

at fixed concentrations of $S$-adenosyl-L-methionine gave intersecting lines (Fig. 4). The initial velocity data was consistent with a sequential binding mechanism where both substrates must bind to the enzyme prior to any product release, thus excluding a ping-pong mechanism.

The order of substrate binding and product release was determined from product inhibition studies. $S$-Adenosyl-Lhomocysteine was a competitive inhibitor of $S$-adenosyl-Lmethionine (Fig. 5A) and noncompetitive with respect to 5-hydroxyferulic acid (Fig. 5B). Sinapic acid was a noncompetitive inhibitor with respect to both $S$-adenosyl-Lmethionine (Fig. 5C) and 5-hydroxyferulic acid (Fig. 5D). These kinetic patterns were consistent with an ordered bi bi mechanism where $S$-adenosyl-L-methionine is the first substrate to bind to the enzyme, followed by 5-hydroxyferulic acid. The first product released is sinapic acid, followed by $S$-adenosyl-L-homocysteine.

The kinetic constants $K_{\mathrm{a}}, K_{\mathrm{b}}, K_{\mathrm{ia}}, K_{\mathrm{ip}}$, and $K_{\mathrm{iq}}$ were calculated from the intercept and slope replots of the generated data (Segel 1975) and are listed in Table 3.

\section{Discussion}

Brassica $O$-methyltransferase was purified to apparent homogeneity by a combination of conventional, FPLC, and affinity chromatography. The purification protocol described here resulted in the recovery of two methylating activities (isoforms I and II), which eluted at two different salt concentrations and exhibited two distinct pIs and product ratios, although the enzymatic activity of isoform II was lost on affinity chromatography. Both isoforms catalyzed the methylation of caffeic and 5-hydroxyferulic acids, yet to a different extent. However, this behavior may be due to differences in the physical environment of the active sites of both isoforms, which may be revealed by their amino acid sequence. These isoforms have been consistently reproduced even after excluding the ammonium sulfate precipitation, thus reducing the possibility that they were artifacts resulting from protein aggregation.

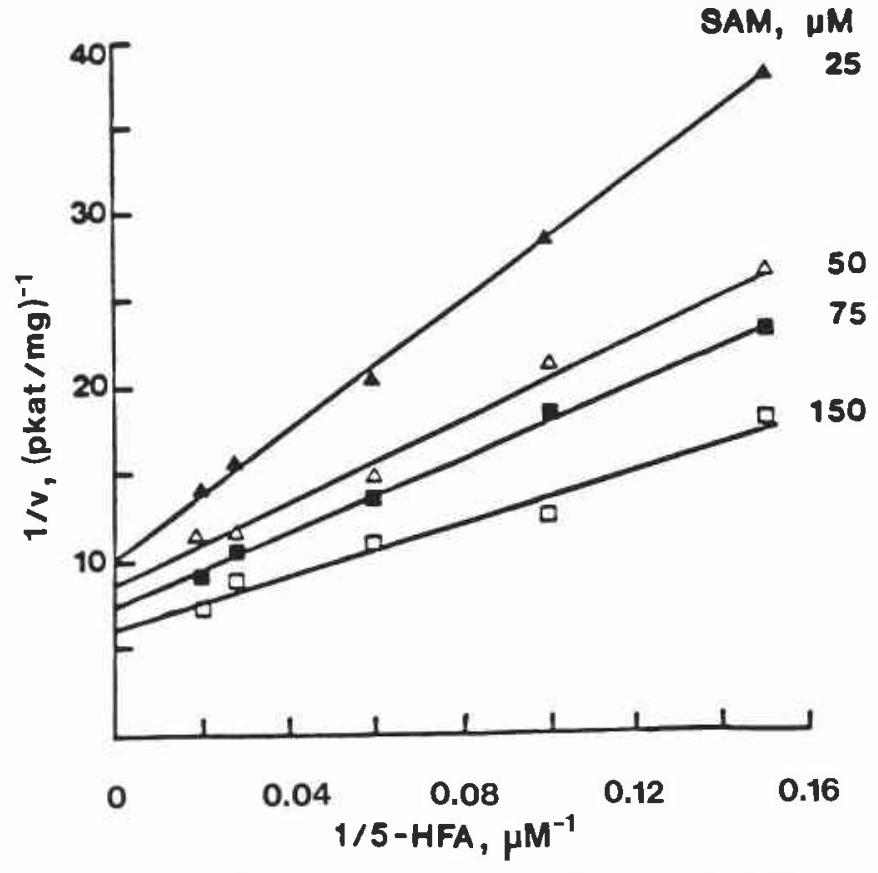

FIG. 4. Double-reciprocal plot of the $O$-methylation of 5-hydroxyferulic acid. S-Adenosyl-L-methionine concentrations were fixed with 5-hydroxyferulic acid as the variable substrate. Varying concentrations of $S$-adenosyl-L-methionine were used containing $0.05 \mu \mathrm{Ci}$. 5-HFA, 5-hydroxyferulic acid; SAM, $S$ adenosyl-L-methionine.

Multiple forms of various enzymes have been observed in plants. These include phenylalanine ammonia lyase (Alibert et al. 1972), chalcone synthase (Beerhues and Wiermann 1985), tyrosine aminotransferase (De-Eknamkul and Ellis 1987), and phenylpropanoid $O$-methyltransferase (Legrand et al. 1976; Tsang and Ibrahim 1979). Furthermore, two forms of the catechol $O$-methyltransferase have also been characterized in rat liver (Axelrod and Vesell 1970).

Members of the Brassicaceae are known to accumulate sinapine (sinapoylcholine) during active growth of the developing embryo (Strack et al. 1983). The existence of the two forms of $O$-methyltransferase activities in cabbage leaves suggests the presence of two spatial cytoplasmic compartments. One of these compartments may be specialized in the biosynthesis of sinapine, whereas the other may catalyze the $O$-methylation of both caffeic and 5-hydroxyferulic acids, leading to the production of lignin precursors (ferulic and sinapic acids, respectively). Both processes may proceed with different rates during growth and development. The detection of sinapine, as well as both isoforms, at different stages of plant growth support this view. However, the localization of the $O$-methyltransferase activities in cabbage by immunocytochemical techniques may reveal their physiological significance based on their compartmentation pattern, as has been demonstrated with the two anthranilate synthase isoforms of Nicotiana tabacum (Brotherton et al. 1986).

The data obtained from the substrate interaction kinetics and inhibition studies are consistent with the ordered bi bi mechanism of other phenylpropanoid (Sharma and Brown 1979) and flavonoid $O$-methyltransferases (Khouri et al. $1988 a, 1988 b$ ). This is in contrast with the catechol $O$-methyltransferase of rat liver, which exhibited a random bi bi mechanism (Flohe and Schwabe 1970). The latter 

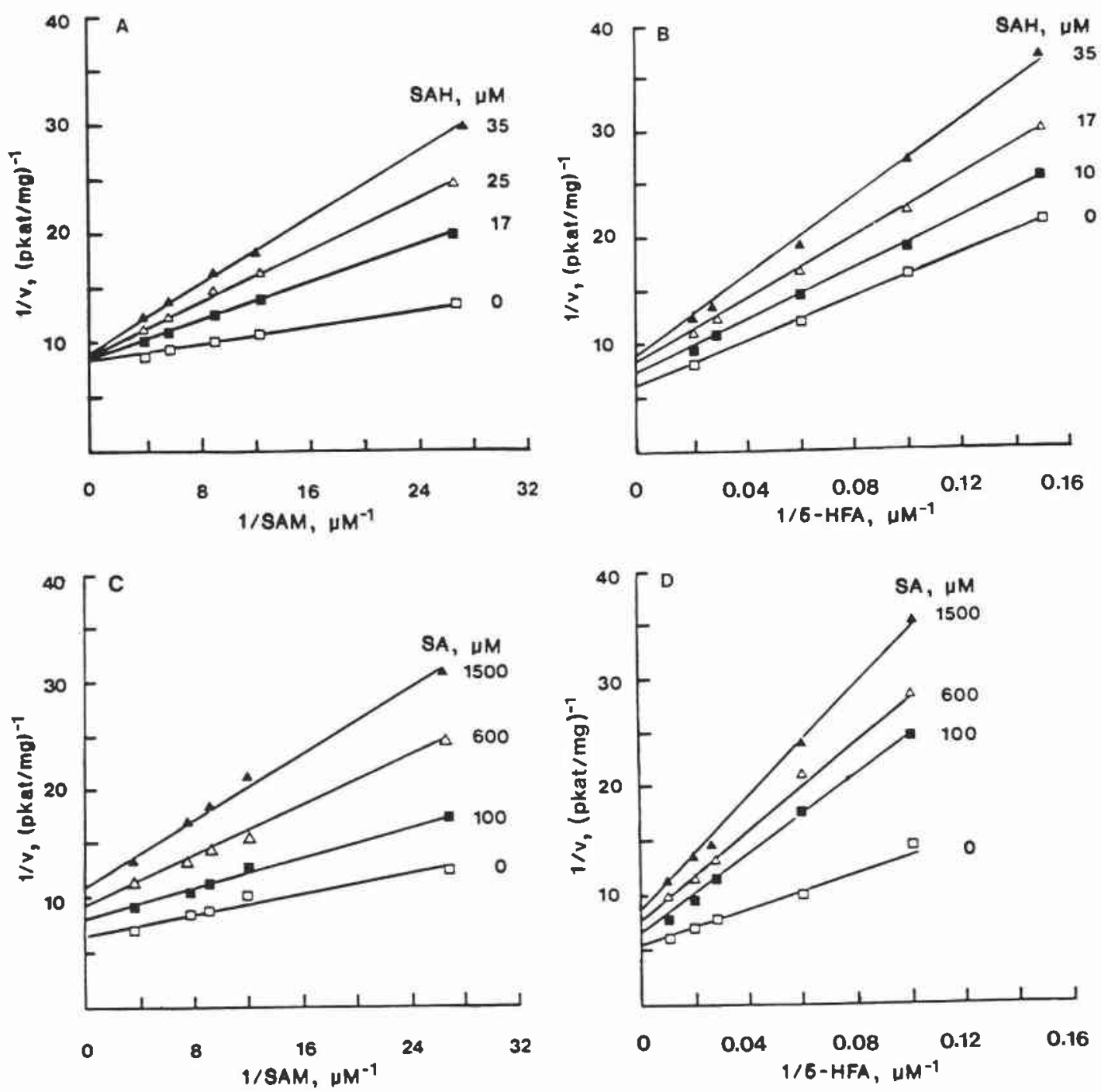

FIG. 5. Product inhibition kinetics of the $O$-methyltransferase. (A) Inhibition by $S$-adenosyl-L-homocysteine with $S$-adenosyl-Lmethionine as the variable substrate, at fixed 5-hydroxyferulic acid concentration ( $35 \mu \mathrm{M})$. Varying concentrations of $S$-adenosyl-Lmethionine were used containing $0.05 \mu \mathrm{Ci}$. (B) Inhibition by $S$-adenosyl-L-homocysteine with 5 -hydroxyferulic acid as the variable substrate, at a fixed $S$-adenosyl-L-methionine concentration $(100 \mu \mathrm{M}$ containing $0.05 \mu \mathrm{Ci})$. (C) Inhibition by sinapic acid with $S$-adenosylL-methionine as the variable substrate, at a fixed 5-hydroxyferulic acid concentration ( $35 \mu \mathrm{M})$. Varying concentrations of $S$-adenosylL-methionine were used containing $0.05 \mu \mathrm{Ci}$. (D) Inhibition by sinapic acid with 5-hydroxyferulic acid as the variable substrate, at a fixed $S$-adenosyl-L-methionine concentration $(100 \mu \mathrm{M})$ containing $0.05 \mu \mathrm{Ci})$. SAH, $S$-adenosyl-L-homocysteine; SAM, $S$-adenosyl-Lmethionine; 5-HFA, 5-hydroxyferulic acid; SA, sinapic acid.

mechanism is unlikely for the cabbage enzyme, since product inhibition patterns indicate that $S$-adenosyl-Lmethionine and $S$-adenosyl-L-homocysteine are competitive, whereas those of 5-hydroxyferulic and sinapic acids are noncompetitive, thus suggesting that $S$-adenosyl-L-methionine must bind first to the free enzyme form. The kinetic constant $K_{\text {ip }}$ was found to be unusually high when compared with other $K_{\text {ip }}$ constants of $O$-methyltransferases (Khouri et al. $1988 a, 1988 b$ ). This indicates that the cabbage enzyme continues to synthesize sinapic acid, despite the already high amount present in the plant cell.

\section{Acknowledgements}

This work was supported by grants from the Natural Sciences and Engineering Research Council of Canada and the Department of Higher Education, Government of Quebec. We wish to thank Dr. M. Legrand for a sample of adenosine-agarose and for his helpful discussions.
Alibert, G., RANJEVA, R., and Boudet, A. 1972. Localisation intracellulaire de la phenylalanine ammoniaque-lyase, de la cinnamate 4-hydroxylase et de la "benzoate synthase"'. Biochim. Biophys. Acta, 279: 282-289.

AXELROD, J., and VESELL, E.S. 1970. Heterogeneity of $N$ - and $O$-methyltransferases. Mol. Pharmacol. 6: 78-84.

BEERHUES, L., and WiERMANN, R 1985. Two different chalcone synthase activities from spinach. Z. Naturforsch. 40C: 160-165.

BRADFORD, M.M. 1976. A rapid and sensitive method for the quantitation of microgram quantities of protein utilizing the principle of protein-dye binding. Anal. Biochem. 72: 248-254.

Brotherton, J.E., HauptManN, R.M., and Widholm, J.M. 1986. Anthranilate synthase forms in plants and cultured cells of Nicotiana tabacum L. Planta, 168: 214-221.

De-Eknamkul, W., and Ellis, B.B. 1987. Purification and characterization of tyrosine aminotransferase activities from Anchusa officinalis cell cultures. Arch. Biochem. Biophys. 257: 430-438.

Dumas, B., Legrand, M., Geoffroy, P., and Fritig, B. 1988. Purification of tobacco $O$-methyltransferase by affinity 
chromatography and estimation of the rate of synthesis of the enzymes during hypersensitive reaction to virus infection. Planta, 176: $36-41$.

Flohe, L., and SchwaBe, K.-P. 1970. Kinetics of purified catechol $O$-methyltransferase. Biochim. Biophys. Acta, 220: 469-476.

Hermann, C., Legrand, M., Geoffroy, P., and Fritig, B. 1987. Enzymatic synthesis of lignin: Purification to homogeneity of the three $O$-methyltransferases of tobacco and production of specific antibodies. Arch. Biochem. Biophys. 253: 367-376.

KHOURI, H.E., DE LUCA, V., and IBRAHIM, R.K. 1988a. Enzymatic synthesis of polymethylated flavonols in Chrysosplenium americanum. Arch. Biochem. Biophys. 265: 1-7.

Khouri, H.E., Tahara, S., and Ibrahim, R.K. 1988b. Partial purification, characterization and kinetic analysis of isoflavone 5-O-methyltransferase from yellow lupin roots. Arch. Biochem. Biophys. 262: 592-598.

Legrand, M., Fritig, B., and Hirth, L. 1976. Catechol $O$-methyltransferase of tobacco: evidence for several enzymes with para- and meta-O-methylating activities. FEBS Lett. 70: 131-136.

PoultoN, J.E. 1981. Transmethylation and demethylation reactions in the metabolism of secondary plant products. In The Biochemistry of Plants. Vol. 7. Edited by R.K. Stumpf and E.E. Conn. Academic Press, New York. pp. 668-723.

SEgEL, I.H. 1975. Enzyme Kinetics. Wiley-Interscience Publications, New York. pp. 506-624.
SARKANEN, S.V., and LudwIG, C.H. 1971. Lignins. WileyInterscience, New York.

ShARMA, S.K., and BRown, S.A. 1979. Affinity chromatography of Ruta graveolens L. O-methyltransferases. Studies demonstrating the potential of the technique in the mechanistic investigation of $O$-methyltransferases. Can. J. Biochem. 57: 986-994.

Shimada, M., Ohashi, H., and Higuchi, T. 1970. $O$ Methyltransferases involved in the biosynthesis of lignins. Phytochemistry, 9: 2463-2470.

STRACK, D., KNOGGE, W., and DAHLBENDER, B. 1983. Enzymatic synthesis of sinapine from 1-O-sinapoyl-D-glucose and choline by a cell-free system from developing seeds of red radish (Raphanus sativus). Z. Naturforsch. 38C: 21-27.

THOMPSON, J.H., SHARMA, S.K., and BROWN, S.A. 1978. $O$-Methyltransferases of furanocoumarin biosynthesis. Arch. Biochim. Biophys. 188: 272-281.

TSANG, Y.F., and IBRAHIM, R.K. 1979. Two forms of $O$ methyltransferase in tobacco cell suspension culture. Phytochemistry, 18: 1131-1136.

VORSATZ, F. 1936. Improvement in the synthesis of hydroxycinnamic acids. J. Prakt. Chem. 145: 265-269.

WEBER, K., and OSBORN, M. 1969. The reliability of molecular weight determinations by dodecyl sulfate - polyacrylamide gel electrophoresis. J. Biol. Chem. 244: 4406-4412. 